JURNAL ILMU PENDIDIKAN DAN EKONOMI

Halaman Jurnal: https://journal.staidenpasar.ac.id/index.php/wb

Halaman Utama Jurnal : https://journal.staidenpasar.ac.id/index.php

\title{
STRATEGI PENGHIMPUNAN DAN PENYALURAN ZAKAT, INFAK, DAN SEDEKAH (ZIS) DALAM PROGRAM SEBAR SEMBAKO PADA MASA PANDEMI COVID-19 DI BADAN AMIL ZAKAT NASIONAL (BAZNAS) PROVINSI BALI
}

\author{
Eka Suci Fitriani ${ }^{1}$, Raden Agrosamdhyo ${ }^{2}$, Ely Mansur ${ }^{3}$ \\ ${ }^{1}$ Ekonomi Syariah,Sekolah Tinggi Agama Islam Denpasar Bali, \\ Denpasar-Indonesia
}

e-mail: \{ ekasucifitriani068@gmail.com, ragrosamdhyo@gmail.com, elymansur1973@gmail.com\}

\begin{abstract}
ABSTRAK
Dalam membantu masyarakat yang terdampak akibat dari pandemi wabah Covid-19, Baznas melakukan operasi pengelolaan ZIS dengan strategi penghimpunan dan penyaluran ZIS dalam bentuk program penyaluran Sembako untuk masyarakat yang terdampak langsung pandemi Covid-19. Tujuan penelitian yaitu Untuk mengetahui Strategi Penghimpunan ZIS Dan Penyaluran ZIS Dalam Program Sebar Sembako Pada Masa Pandemi Covid-19 di Baznas Provinsi Bali. Metode penelitian ini dengan kualitatif deskriptif. Informan 10 orang yang dipilih dengan menggunakan teknik purposive. Pengumpulan data melalui observasi, wawancara dan dokumentasi. Sedangkan teknik analisis data menggunakan reduksi data, penyajian data, penyimpulan dan verifikasi serta kesimpulan akhir. Hasil penelitian menunjukkan bahwa: (1) Strategi penghimpunan ZIS oleh Baznas meliputi Sosialisasi kepada Instansi pemerintah tingkat I, lembaga keuangan, dan majelis ta'lim, mengirimkan laporan pertanggung jawaban keuangan, mempromosikan program melalui tiga media yaitu media cetak, media sosial, dan media elektronik, memberi pelayanan pembayaran ZIS dengan cara pembayaran langsung, jemput zakat, membentuk UPZ di lembaga pemrintahan dan swasta, membuka rekening di beberapa Bank, scan barcode dan menjalin hubungan yang baik dengan muzaki/donatur, (2) Strategi penyaluran ZIS meliputi kepatuhan terhadap ketentuan syariah dan sesuai dengan UU, mengikuti protokol penanganan Covid-19 dengan physical distancing, social distancing, dan penggunaan masker, pendekatan penyaluran antara push approach dan pull approach, memberikan surat tembusan kepada gugus tugas Covid-19..
\end{abstract}

Kata kunci: Strategi Penghimpunan ZIS dan Strategi Penyaluran ZIS

\begin{abstract}
In assisting the affected communities as a result of the Covid-19 pandemic, Baznas carried out ZIS management operations with a ZIS collection and distribution strategy in the form of a basic food distribution program for people directly affected by the Covid-19 pandemic. The purpose of this research is to find out the strategy of ZIS Collection and Distribution of ZIS in the Distribution of Grocery Programs during the Covid-19 Pandemic Period in the Bali Provincial Baznas. This research method uses descriptive qualitative method. 10 informants were selected using a purposive technique. Data collection through observation, interviews and documentation. While data analysis techniques use data reduction, data presentation, inference and verification as well as final conclusions. The results of the research show that: (1) ZIS collection strategies by Baznas include socialization to government level I institutions, financial institutions, and majelis ta "lim, sending financial accountability reports, promoting programs through three media namely print media, social media, and media electronic, providing ZIS payment services by direct payment, picking up zakat, forming UPZ in government and private institutions, opening accounts in several banks, scanning barcodes and establishing good relationships with muzaki / donors, (2) ZIS distribution strategies include compliance with regulations sharia and in accordance with the law, following the Covid-19 handling protocol with physical distancing, social distancing, and the use of masks, the distribution approach between push approach and pull approach, giving a copy to Covid-19 task force.
\end{abstract}

Keywords: ZIS Collection Strategy and ZIS Distribution Strategy 


\section{PENDAHULUAN}

Akhir tahun 2019 dunia dihadapi dengan satu wabah Virus mematikan yang berasal dari Kota Wuhan Provinsi Hubei, Tiongkok, China yaitu virus Covid-19 atau Corona Virus Disease 19. Dalam waktu kurang dari tiga bulan Covid-19 telah memasuki Indonesia dengan diumumkannya kasus positif Covid-19 petama kali oleh Presiden Joko Widodo pada tanggal 3 Maret 2020. Pengumuman tersebut menimbulkan kehawatiran dan ketakutan untuk seluruh masyarakat Indonesia.

Adanya korban positif Covid-19 membuat pemerintah melakukan strategi pemutusan rantai penyaluran virus Covid-19 berdasarkan anjuran organisasi kesehatan dunia yaitu World Hearth Organization (WHO) dengan melakukan physical distancing yaitu menjaga jarak fisik antar manusia, selalu menjaga kebersihan tangan dengan mencuci tangan dengan air bersih dan sabun ataupun menggunakan cairan antiseptik berbahan dasar alcohol dan selalu memakai masker. Selain itu pemerintah juga membuat aturan kerja dari rumah atau work from home (WFH) untuk mencegah, mengurangi dan melindungi pegawai dari penyebaran Covid-19. WHO juga telah mengumumkan bahwa Covid-19 sebagai pandemi global yaitu menyebar di seluruh dunia.

Pandemi Covid-19 ini memberikan banyak dampak negatif terhadap kehidupan manusia terutama dampak terhadap perekonomian rakyat. Salah satu dampak terhadap perekonomian adalah banyaknya pekerja yang dirumahkan dan bahkan terdampak Pemutusan Hubungan Kerja (PHK). Hadirnya pandemi Covid-19 yang memutus tali perekonomian dunia khususnya di Indonesia, berdampak terhadap banyaknya menusia yang tidak dapat memenuhi kebutuhan hidupnya bahkan untuk kebutuhan dasar yaitu makan.

Terputusnya tali perekonomian yang berdampak terhadap tidak terpenuhinya kebutuhan manusia, memanggil Badan Amil Zakat Nasional (BAZNAS) Provinsi Bali untuk melakukan kegiatan penghimpunan ZIS yang diperuntukan dalam penyaluran paket sembako kepada masayarakat yang terdampak pandemi Covid-19. Islam mengajarkan kita sebagai umatnya untuk berbagi dengan mereka yang membutuhkan bahkan disaat sedang dalam keadaan sulitpun seperti firman Allah Swt surat AlBaqarah ayat 267:

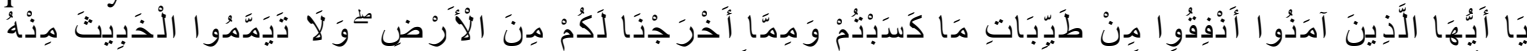

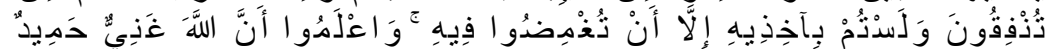

Terjemahan: Wahai orang-orang yang beriman! Infakkanlah sebagian dari hasil usahamu yang baik-baik dan sebagian dari apa yang kami keluarkan dari bumi untukmu. Janganlah kamu memilih yang buruk untuk kmau keluarkan, padahal kamu sendiri tidak mau mengambilnya melainkan dengan memicingkan mata (enggan) terhadapnya. Dan ketahuilah bahwa Allah maha kaya, maha terpuji. ${ }^{1}$

Berdirinya Baznas sebagai lembaga sosial yang salah satunya berperan sebagai penyalur dana ZIS mengajak masyarakat untuk ikut serta dalam membantu sesama, sebagaimana Allah berfirman dalam surat An-Nisa ayat 114:

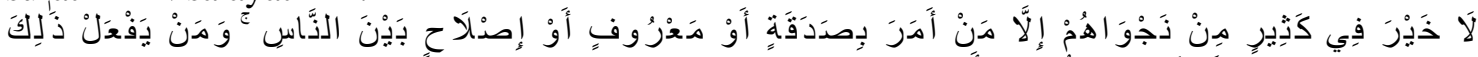

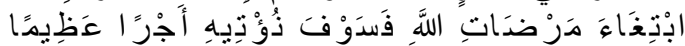

Terjemahan: Tidak ada kebaikan dari banyak pembicaraan rahasia mereka, kecuali pembicaraan rahasia dari orang yang menyuruh (orang) bersedekah, atau berbuat kebaikan, atau mnegadakan perdamaian diantara manusia. Barang siapa berbuat demikian karena mencari keridaan Allah, maka kelak kami akan memberinya pahala yang besar. ${ }^{2}$

Selain berdasarkan ketentuan syariah, penghimpunan dan penyaluran ZIS yang dilaksanakan oleh Baznas Provinsi Bali tertera pada UU No 23 Tahun 2011 yang menugaskan Baznas sebagai lembaga pemerintahan nonstruktural yang bersifat mandiri dan bertanggung jawab kepada Presiden melalui Mentri. Baznas dibentuk langsung sebagai Badan Pengelolaan Zakat Nasional yang melaksanakan tugas sebagai pengumpulan, pendistribusian dan pendayagunaan zakat.

Kegiatan penghimpunan dan penyaluran ZIS dalam program sebar sembako guna meringankan sebagian mereka yang membutuhkan, dijalankan oleh Baznas tahun ini tentunya memiliki strategi

\footnotetext{
${ }^{1}$ Departemen RI, Al-Quran Terjemah dan Tajwid, (Bandung: Sygma, 2014), h. 85

${ }^{2}$ Ibid., h. 187
} 
yang berbeda dengan strategi yang biasa dilakukan saat sebelum adanya pandemi Covid-19. Dalam penghimpunan dan penyaluran ZIS harus mengikuti protokol kesehatan penanganan Covid-19.

Berdasarkan keterangan latar belakang di atas, maka penulis tertarik melakukan penelitian dan pengkajian lebih lanjut mengenai "Strategi Penghimpunan dan Penyaluran ZIS Dalam Program Sebar Sembako Pada Masa Pandemi Covid-19 di Baznas Provinsi Bali"

Fokus permasalahan dalam penelitian ini adalah bagaimana strategi penghimpunan ZIS dalam program sebar sembako pada masa pandemi covid-19 di Baznas Provinsi Bali? dan Bagaimana strategi penyaluran ZIS dalam program sebar sembako pada masa pandemi covid-19 di Baznas Provinsi Bali?.

Untuk mendapatkan jawaban dari fokus permasalahan dalam penelitian tersebut, maka peneliti melakukan kajian melalui metode deskriptif kualitatif sebagaimana paparan pada bagian metode penelitian dalam artikel ini.

Tujuan penelitian ini adalah untuk mengetahui strategi penghimpunan ZIS dalam program sebar sembako pada masa pandemi covid-19 di BaznasProvinsi Bali dan strategi penyaluran ZIS dalam program sebar sembako pada masa pandemi covid-19 di Baznas Provinsi Bali.

\section{METODE PENELITIAN} Indonesia

Penelitian ini dilakukan di Baznas Provinsi Bali Jalan. Jaya Giri No.81 A, Denpasar, Bali,

Penelitian ini menggunakan metode deskriptif dengan pendekatan kualitatif menghasilkan data deskriptif berupa ucapan atau tulisan dan perilaku orang-orang yang diamati. Penentuan informan menggunakan teknik purposive sehingga didapat informan yang tepat dalamm penelitian ini adalah Ketua Umum, Wakil Ketua II Bidang Pendistribusian dan Pendayagunaan, Kepala Pelaksana Bidang Penghimpunan, Staff Operasional, Muzaki, dan Mustahik.

Tabel 1 Data Informan Pejabat Baznas Provinsi Bali

\begin{tabular}{|c|l|l|}
\hline No & \multicolumn{1}{|c|}{ Nama } & \multicolumn{1}{|c|}{ Jabatan } \\
\hline 1 & $\begin{array}{l}\text { DRS. H. } \\
\text { Mahrusun, } \\
\text { M.Pd.I }\end{array}$ & $\begin{array}{l}\text { Ketua Baznas } \\
\text { Provinsi Bali }\end{array}$ \\
\hline 2 & $\begin{array}{l}\text { H. Khairuddin, } \\
\text { S.Pd.I }\end{array}$ & $\begin{array}{l}\text { Wakil Ketua II } \\
\text { Baznas Provinsi } \\
\text { Bali }\end{array}$ \\
\hline 3 & $\begin{array}{l}\text { Ahmad } \\
\text { Arrasyid, S.E.I }\end{array}$ & $\begin{array}{l}\text { Kepala Pelaksana } \\
\text { Bidang } \\
\text { Penghimpunan } \\
\text { (KPBP) Zakat } \\
\text { Baznas Provinsi } \\
\text { Bali }\end{array}$ \\
\hline 4 & $\begin{array}{l}\text { Staff Operasional } \\
\text { Baznas Provinsi } \\
\text { Bali }\end{array}$ \\
\hline
\end{tabular}

Sumber: Data diolah 2020

Tabel 2 Data Informan Muzaki Baznas Provinsi Bali

\begin{tabular}{|c|l|l|}
\hline No & \multicolumn{1}{|c|}{ Nama } & \multicolumn{1}{c|}{ Pekerjaan } \\
\hline 1 & Irdawati & Dosen \\
\hline
\end{tabular}

Sumber: Data diolah 2020 
Tabel 3 Data Informan Mustahik Baznas Provinsi Bali

\begin{tabular}{|c|l|l|}
\hline No & \multicolumn{1}{|c|}{ Nama } & \multicolumn{1}{|c|}{ Pekerjaan } \\
\hline 1 & Siti Aminah & Ibu Rumah Tangga \\
\hline 2 & Arif & $\begin{array}{l}\text { Bendahara Yayasan } \\
\text { Birrul Walidain }\end{array}$ \\
\hline 3 & $\begin{array}{l}\text { Yuli Firdiani, } \\
\text { M.Pd.I }\end{array}$ & $\begin{array}{l}\text { Sekertaris Yayasan } \\
\text { Tunas Bangsa }\end{array}$ \\
\hline 4 & $\begin{array}{l}\text { Savio Bhirawa } \\
\text { Anoraga } \\
\text { Muchtar }\end{array}$ & $\begin{array}{l}\text { Devisi Bidang } \\
\text { Sosial Yayasan } \\
\text { SPMAA Bali }\end{array}$ \\
\hline 5 & Armiati & $\begin{array}{l}\text { Pembina Anak } \\
\text { Yatim Yayasan Al- } \\
\text { Ittihad Rasyid wa } \\
\text { Wahabib }\end{array}$ \\
\hline
\end{tabular}

Sumber: Data diolah 2020

Untuk mendapatkan data atau informasi, digunakan; pertama, teknik observasi, penulis mengamati dan mencatat kegiatan yang terjadi di Baznas Provinsi Bali terkait kegiatan penghimpunan dan penyaluran ZIS dalam program Sebar Sembako di masa pandemi Covid-19; kedua, teknik wawancara, penulis menggali informasi terkait fokus penelitian yang penulis tentukan dengan teknik purposive kepada Ketua Umum, Wakil Ketua II Bidang Pendistribusian dan Pendayagunaan, Kepala Pelaksana Bidang Penghimpunan, Staff Operasional, Muzaki, dan Mustahik; ketiga, dokumentasi, informasi atau data yang penulis dapatkan dari dokumen-dokumen yang terdapat di Baznas Provinsi Bali.

Langkah-langkah analisis data dalam penelitian diskriptif kualitatif ini, yaitu dengan; reduksi data, penyajian data, penyimpulan dan verifikasi, dan kesimpulan akhir. Reduksi data berupa proses merangkum, memilih hal-hal pokok dan difokuskan kepada hal yang penting, penyajian data yakni menkategorisasikan menurut pokok permasalahan dan dibuat dalam bentuk matriks sehingga memudahkan peneliti untuk melihat pola-pola hubungan satu data dengan data lainnya. Penyimpulan dan Verifikasi Data yang sudah direduksi dan disajikan secara sistematis akan disimpulkan sementara. Kesimpulan yang diperoleh pada tahap awal biasanya kurag jelas, tetapi pada tahap-tahap selanjutnya akan semakin tegas dan memiliki dasar yang kuat. Kesimpulan sementara perlu diverifikasi. Teknik yang dapat digunakan untuk memverifikasi adalah triangulasi sumber data dan metode, diskusi temn sejawat dan pengecekan anggota. Sementara Kesimpulan akhir diperoleh berdasarkan kesimpulan sementara yang telah diverifikasi. Kesimpulan final ini diharapkan dapat diperoleh setelah pengumpulan data selesai.

\section{HASIL DAN PEMBAHASAN}

Hasil yang didapatkan berdasarkan data yang diperoleh melalui teknik observasi, wawancara, dan dokumentasi di Baznas Provinsi Bali, maka dapat di paparkan hasil penelitian dan pembahasan sebagai berikut.

\section{Strategi Penghimpunan ZIS Dalam Program Sebar Sembako Pada Masa Pandemi Covid-19 di BAZNAS Provinsi Bali}

Analisa kebutuhan merupakan unsur awal bagi para tim fundraising guna meningkatkan kepercayaan para muzaki/donatur dengan memberikan pelanyanan yang baik kepada para muzaki/donatur. Dalam menarik kepercayaan muzaki/donattur utnuk menunaikan zakat, ifak, dan sedekahnya di Baznas Provinsi Bali yang dilakukan adalah dengan memberikan sosialisasi baik secara tatap muka (face to face) maupun sosialisasi non face to face, menyebarkan kegiatan yang sudah dilakukan oleh Baznas Provinsi Bali melalui media cetak dan media sosial, serta hal terpentine vg adalah memberikan pelaporan keuangan dan bukti setor zakat muzaki/donatur..

"Pada awalnya kita melakukan eee sosialisasi sesuai dengan sasaran Baznas Provinsi Bali yaitu instansi dan lain-lain, ya itu itu yang pertama, walaupun undang-undang sudah,,, yang terakhir 
2011 itu banyak yang masyarakat yang tidak mengetahui sehingga yang tadi pertama sosialisasi tatap muka langsung dan yang berikutnya adalah lewat media cetak, ya jadi kita menyebarkan brosur mengenai kegiatan kita, kemudian juga eee disamping itu juga menggunakan eee media elektronik ya.."”

Pelaporan keuangan merupakan hal utama yang diberikan Baznas Provinsi Bali kepada muzaki/donatur guna mempertahankan kepercayaan para muzaki/donatur terhadap Baznas Provinsi Bali dengan prdikat pelaporan WTP (wajar Tanpa Pengecualian) dimana laporan keuangan tersebut menyajikan secara wajar, dalam semua hal yang material dan laporan keuangan boleh diketahuioleh publik terkait seberapa besar penghimpunan dan penyaluran dana yang sudah terpakai. Pernyataan tersebut dibenarkan oleh ketua Baznas Provinsi Bali,

"Ya, pasti. Jadi khusus Zakat itu pasti. Karena di dalam penyaluran zakat itu kalau tidak ada katakanlah laporan itu merupakan satu masalah. Indikatornya jika tidak menyampaikan laporan bisa kena tuntutan. Jadi oleh karena itu laporan keuangan yang meliputi kita sudah menerima uang atau sudah menerima apa yang menjadi kehendak dari pada muzakki, jadi kemudian yang kedua laporan dalam bentuk brosur, kalau dalam bentuk brosur itu sifatnya umum. Jadi eee dana dari pada masyarakat ini sudah digunakan untuk apa saja? Itu semuanya ada di itu. Apalagi kita juga setiap tahun diaudit oleh akuntan publik, terutama di bidang keuangan itu dan lain-lain ya itu WTP ( Wajar Tanpa Pengecualian) jadi pasti kita laporkan"4

Selain dalam bentuk pelaporan dan sosialisasi tentang zakat, infak dan sedekah Baznas Provinsi Bali juga memberikan pelayanan terhadap para muzaki/donatur yang salah satu pelayanannya ialah dengan memberikan berbagai pelayanan pembayaran yaitu dengan pelayanan jemput zakat termasuk infak dan sedekah berapapun nominal yang akan disalurkan.

"Kita melakukan namanya jemput zakat. Jadi berapapun nominalnya sebenarnya. Jadi kita tetap memberikan pelayanan yang terbaik"

Selain itu dalam memberikan kemudahan menunaikan ZIS maka Baznas Provinsi Bali juga memberikan pelayanan dengan membuka rekening di berbagai Bank, sehingga muzaki/donatur dapat dengan mudah membayar dana ZIS yang akan disalurkan. Disamping itu juga Baznas Provinsi Bali juga membuka kemudahan pembayaran dengan hanya scan barcode beberapa aplikasi yang sudah bekerja sama dengan Baznas Provinsi Bali.

Pendapat tersebut di atas disampaikan secara mendalam oleh Bapak Riang,

"Sekarang kan sudah di Era digitalkan ya. Semua sudah mellek tehnologi, itu memudahkan. Apalagi di pandemi seperti ini rata-rata sekarang entah itu menggunakan aplikasi DANA, OVO, Go Pay Ataupun Qris ya sekarang ya Populer karena semuanya dikelola oleh orang Indonesia. Scan barcode bisa dengan OVO. DANA, Go Pay,Cimb Niaga Syariah Barcode, Bank Syariah Mandiri Barcode. Selain itu ada kerja sama dengan beberapa Bank, BSM, BNI Syariah, BRI Syariah, BNI Konvensional, BRI Konvensional, Bank Muamalat, Bank Cimb Niaga Syariah”6

Hal yang sama diutarakan oleh ketua Baznas Provinsi Bali yang menyampaikan,

“..jadi misalnya pembayaran itu dengan penggunaan go pay macam-macam itu..”

Pada dasarnya segmentasi hanya dilakukan guna menentukan strategi dalam penghimpunan dana, namun terkadang beberapa donatur meminta beberapa strategi penyaluran terhadap dana yang sudah disalurkan melalui Baznas Provinsi Bali.

"Ya sebenarnya dia tidak memiliki strategi tapi tuntunan dan keadaan jadi strateginya dari kita. Contoh misalnya seperti itu tadi orang tidak mau lagi datang bayar cash itu tidak mau, sehingga kita kemudian dengan membuka berbagai cara supaya ya orang mudah eee menunaikan zakat"7

"Kalo donatur iya, karena donatur kan biasanya... BUMN, BUMD ataupun perorangan. Mereka mempunyai perusahaan, yang dimana mereka mempunyai dana yang besar. Yang dimana program-programnya itu, prgram yang kita buat besar, ya otmomatis kita sesuaikan dengan

\footnotetext{
${ }^{3}$ Mahrusun, Ketua Baznas Provinsi Bali, Wawancara Pribadi, Denpasar 4 Juni 2020

${ }^{4}$ Ibid.,

${ }^{5}$ RiangBagus Dwi Anto, Staff Operasional Baznas Provinsi Balli, Wawancara Pribadi, Denpasar 8 Juni

${ }^{6}$ Mahrusun, Ketua Baznas Provinsi Bali, Loc. Cit

${ }^{7}$ Ibid.
} 2020 
donatur, karena mereka bisa menggunakan dana CSR di perusahaannya ataupun dana kebijakan lainnya"8

Identifikasi donatur dalam menentukan sasaran dan target muzaki/donatur Baznas Provinsi Bali melakukan identifikasi terhadap sasaranya. Sasaran dan target Baznas Provinsi Bali yaitu para pengusaha, karyawan swasta dan pemerintah tingkat provinsi, dan masyarakat umum.

Pandangan di atas dikuatkan dengan pernyataan Bapak Rasyid,

"Pengusaha yang kita dapat rekomendasi, kita melakukan pendekatan, silaturahmi, memberikan brosur, dan juga sasaran kita adalah karyawan swasta dan pemerintah, kalau PNS biasanya melalui satu pintu kita bentuk UPZ di kantor pemerintahan tingkat provinsi"9

Baznas Provinsi Bali juga membuka UPZ di instansi pemerinthan tingkat Provinsi. Pendapat ini dibenarkan oleh informan A.4 (Lampiran 11:115) yang menyampaikan,

"Kita membuka UPZ di instansi pemerintahan salah satunya yaitu Angkasa Pura I, kemenag Provinsi Bali, Dinas Kesehatan Provinsi Bali, Kantor Wilayah Pembendaharaan, Balai Besar Pengawasan Obat dan makanan, Direktorat Jendral pajak Bali" 10

Positionig dilakukan guna mendapatkan posisi kepercayaan di hati donatur/masyarakat umum. Terkait hal tersebut yang dilakukan oleh Baznas Provinsi Bali tidak jauh berbeda dengan yang dilakukan dalam menarik kepercayaan muzaki/donatur yaitu dengan mengadakan sosialisasi kepada instansi pemerintah tingkat I, lembaga keuangan, perkumpulan/organisasi masyarakat muslim (pengajian) serta memposting setiap kegiatan mereka di berbagai media sosial baik instagram, facebook, twiter, whatsapp, dan website.

Penyampaian tersebut senada dengan jawaban informan A.4 (lampiran 11:116)

"Yang selama ini kita sudah lakukan ya,, kita berikan bukti setor zakat, kita berikan posterposter tentang perhitungan zakat, perhitungan harta mereka, emas, perak, pertanian, segala macem. Ya dengan sosialisasi lembaga tingkat I karena kita kan di Baznas Provinsi, contohnya Dinas Pendidikan Provinsi Bali, BPN (Badan Pertahanan Nasional), Angkasapura II, Badan Kepegawaian Negara, Kantor Wilayah Kementrian Agama Provinsi Bali. Kita juga sosialisasi ke pengajian-pengajian dengan nara sumber dari Baznas Provinsi Bali" 11

Produk demi lancarnya kegiatan produk yang dimiliki oleh Baznas Provinsi Bali, maka Baznas Provinsi Bali harus pandai mengkomunikasikan penyampaian produknya dengan baik kepada muzaki/donatur. Namun karena terbatasnya SDM (sumber Daya Manusia) di Baznas Provinsi Bali maka strategi komunikasi yang dijalankan dalam penyampaian produknya adalah melalui telepon, staff operasional menyampaikan kepada para muzaki/donatur terkait produk yang dimiliki dengan harapan para muzaki/donatur memiliki ketertarikan dalam berpartisipasi akan berjalannya produk tertentu dengan baik. Para staff operasional juga membagikan program yang akan dijalankan melalui media sosial dalam bentuk poster.

"Yang sudah kami lakukan saat ini ya dengan media sosial ya, melalui facebook, instagram,

bless whatsapp, jadi ketika kita punya info apa tentang zakat, infak, sedekah, program apa yang ada di Baznas Provinsi Bali, kita langsung bless ke handphone kita masing-masing, broad cast lah istilahnya ya"12

Promosi program kegiatan yang akan datang juga tak kalah penting dengan komunikasi produk. Keduanya memiliki strategi yang tidak jauh berbeda, hanya saja dalam promosi ini Baznas Provinsi Bali menggunakan seluruh media baik media cetak, media sosial maupun media elektronik. Media cetak yang digunakan adalah brosur, poster, majalah dan benner, media sosial yang digunakan yaitu facebook dengan akun "baznasprovinsibali", instagramdengan akun @baznasprovbali, whatsapp, dan menggunakan iklan berbayar di internet dengan halaman website Baznas Provinsi Bali yaitu www.baznasbali.com. Media elektronik yang digunakan televisi di channel TVRI dan radio RRI.

\footnotetext{
${ }^{8}$ Riang Bagus Dwi Anto, Staff Operasional Baznas Provinsi Bali, Loc. Cit

${ }^{9}$ Ahmad Arrasyid, Kepala Pelaksana Bidang Penghimpunan (KPBP) Zakat Baznas Provinsi Bali Baznas Provinsi Bali, Wawancara Pribadi, Denpasar 3 Juni 2020

${ }^{10}$ Riang Bagus Dwi Anto, Staff Operasional Baznas Provinsi Bali, Loc. Cit

${ }^{11}$ Ibid.,

${ }^{12}$ Ahmad Arrasyid, KPBP Zakat Baznas Provinsi Bali, Loc. Cit.
} 
"Iya, jadi kita lebih banyak ke brosur yang disampaikan kepada seluruh masyarakat baik yang sifatnya itu brosur tebal maupun brosur yang lebih singkat. Iya, kalau bentuknya seperti facebook, instagram dan macam-macamnya. Iya, terutama televisi. Beberapa kegiatan atau katakanlah eee beberapa sosialisasi kita menggunakan televisi dalam saat-saat tertentu kita mengundang televisi atau juga radi, terutama radio pemerintah. Dengan channel televisi TVRI dan Radio RRI."13

Maintanance juga memiliki peran penting dalam kualitas penghimpunan ZIS. Maintanance dilakukan untuk menjalin hubungan baik dengan para muzaki/donatur Baznas Provinsi Bali dengan cara selalu menjaga silaturahmi baik dengan silaturahmi dengan mendatangi langsung para muzaki/donatur ataupun tudak secara langsung dengan menghubungi para muzaki dan menanyakan keadaan serta memberikan pelaporan keungan Baznas Provinsi Bali kepada muzaki/donatur

"Jadi yang dilakukan pertama adalah pertanggung jawabannya harus jelas, pertanggung jawaban dari BAZNAS dari uang yang dikeluarkan oleh Muzakki atau Donatur. Kedua kalinya setiap ada apa itu ya, ada katakanlah kita mempunyai program kita tawarkan siapa tau dia tertarik dengan berbagi program, yang ketiga kemudian eee apa itu ya sama seperti tadi kita berusaha menjalin atau berkomunikasi dengan para muzaki dan donatur, semuanya diceritakan secara terbuka tidak ada yang ditutup-tutupi. Untuk silaturahmi kita tertentu saja, di lembaga, misal ke Bank dalam rangka menjalin kerjasama ya kita ke Bank. "14

Dalam penelitian yang dilakukan oleh Nurul Sholeh yang berjudul "Strategi Penghimpunan Dan Penyaluran Dana Zakat Pada Lembaga Amil Zakat Al Ihsan Jawa Tengah (LAZIS JATENG) Cabang Kota Semarang (Studi Kepuasan Muzaki Dan Peningkatan, Pendapatan Mustahik)",strategi penghimpunan dana zakat pada LAZIS Jateng cabang Kota Semarang adalah melalui (1) sosialisasi, (2)produk-produk penghimpunan, (3)menjalin kerjasama dan (4) menjalin komunikasi dengan baik.

Perbedaan dengan hasil penelitian yang penulis lakukan dalam penelitian ini hanya terletak pada inovasi stretegi penghimpunan dalam segi komunikasi, promosi produk dan sistem pembayaran zakat strategi yang sama dengan cara yang lebih inovasi. Dalam penelitian yang peneliti lakukan penghimpunan ZIS dilakukan dengan berbagia cara, (1) Menarik kepercayaan muzaki/donatur dengan mengirimkan laporan pertanggung jawaban keuangan, (2) Promosi Produk melalui tiga media yaitu media cetak, media sosial dan media elektronik, (3) Pembayaran ZIS bisa dilakukan dengan berbagai cara yaitu langsung membayar di kantor Baznas Provinsi Bali, pembayaran dengan pelayanan jemput zakat/infak/sedekah,membentuk UPZ di masing-masing lembaga pemerintahan dan swasta seperti Angkasa Pura I; Kemenag Provinsi Bali; Dinas Kesehatan Provinsi Bali; Kantor Wilayah Pembendaharaan; Balai Besar Pengawasan Obat dan makanan; Direktorat Jendral pajak Bali; Pembayaran melalui transfer ke rekening bank yang sudah bekerjasama dengan Baznas Provinsi Bali, dan Pembayaran melalui scan barcode dengan aplikasi yang sudah bekerjasama dengan Baznas Provinsi Bali, (4) Menjalin hubungan yang baik dengan para muzaki/donatur.

\section{Strategi Penyaluran ZIS Dalam Program Sebar Sembako Pada Masa Pandemi Covid- 19 di BAZNAS Provinsi Bali}

Kegiatan penyaluran merupakan salah satu fungsi Baznas. Dalam penelitian ini fokus peneliti selain penghimpunan juga mengenai penyaluran. Dari penelitian ini didapat jawaban mengenai strategi penyaluran ZIS berdasarkan observasi, wawancara dan dokumentasi yang dilakukan oleh paneliti. Kegiatan penyaluran yang dijalankan oleh Baznas Provinsi Bali sudah sesuai ketentuan syariah dan UU. Ketentuan syariah berdasar pada firman Allah surat at-Taubah ayat 60:

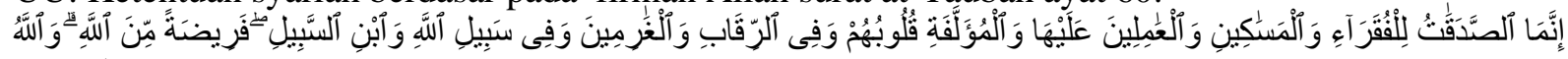
عَليْهُ حَكَيٌْ

Ayat tersebut yang menjadi dasar Baznas Provinsi Bali dalam menyalurkan ZIS untuk sembako. Dalam ayat tersebut dijelaskan bahwa zakat diperuntukan untuk golongan 8 asnaf, yaitu fakir, miskin, amil, orang yang baru masuk islam, hamba sahaya, orang yang berhutang, orang berjuang di jalan Allah, dan orang yang dalam perjalanan. Ketentuan dalam UU berdasar pada UU No 23 Tahun 2011.

\footnotetext{
${ }^{13}$ Mahrusun, Ketua Baznas Provinsi Bali, Loc.Cit.

${ }^{14}$ Ibid.,
} 
"Dengan ketentuan 8 Asnaf terdapat dalam surah at-Taubah ayat 60. Jadi yang 8 asnaf itu terbagi menjadi 6 program. Ada program kesehatan, program Bali Sejahtera, Bali Cerdas, kemudian Bali Sehat. Itu ada enam itu apa namanya program dari pusat ke daerah itu sama.."15

"Sebenarnya dasar dari program ZIS ini adalah disamping Syar'i adalalh menurut undangundang yang No 23 Tahun 2011, termasuk PP (Peraturan Pemerintah, Red), Keputusan Mentri Agama, Peraturan Baznas Pusat, kita mempunyai pedomannya itu. Jadi di samping hukum syar'i nya juga punya undang-undang. Yang tentunya itu bertolak kepada bahaya pandemi untuk pedoman pokonya tidak bisa menyamping dari sana" 16

Penyaluran ZIS untuk sembako tahun ini sangat berbeda dengan penyaluran yang dijalankan tahun-tahun sebelumnnya karena di tahun ini disalurkan bersamaan dengan adanya pandemi covid- 19 . Oleh karena itu penyaluran dilakukan dengan tidak melanggar protokol penanganan Covid-19.

Wakil ketua II Baznas Provinsi Bali membenarkan hal tersebut,

"Iya. Sudah sesuai dengan protokol pemerintah. Jaga jarak, pakai masker.."17

Bentuk penyaluran ZIS tahun ini dikemas dalam paket sembako yang berisikan bahan pokok makanan. Dengan nominal kemasan yang berbeda sesuai dengan sumber penyaluran.

"Beras 5 kilo, Mie Instan, Mie Telor, Teh, Minyak Goreng, dan Masker."18

“... Dengan nominal yang berbeda ada yang Rp. 100.000,- ada yang Rp. 75.000, bedanya yang

Rp. 75.000 dari donatur kalau yang Rp. 100.000,- dari muzakki"'19

Pendekatan penyaluran yang digunakan adalah mix antara push approach dan pull approach. Push approach disalurkan hanya kepada lembaga seperti panti asuhan, panti jompo dan lembaga pendidikan. Sedangkan untuk penyaluran perorangan/pribadi penyaluran dilakukan dengan para mustahik langsung hadir ke kantor Baznas Provinsi Bali.

"Tetap ada perkumpulan tapi tetap menjaga jarak. Namun tidak banyak. Tp untuk penyaluran di panti asuhan kita tetap ada social distancing hanya terbatas antara 10-15 oranglah"20

Koordinasi dengan pemerintah gugus tugas Covid-19. Setiap kegiatan yang dijalankan oleh Baznas Provinsi Bali mengirim surat tembusan ke kantor BPD Bali.

Selain itu Baznas Provinsi Bali sebelumnya juga berkkoordniasi dengan MUI crisis center Bali dengan menyapaikan segala kegiatan yang dijalankan dalam program ini dan setiap amil diberikan surat tugas.

"Iya. Kita memberikan surat tembusan saat melakukan kegiatan program kepada satgas

Provinsi Bali yang ada dii BPD Provinsi Bali. Dan setiap amil sudah dibuatkan surat tugas masing-masing."21

Dalam penelitian yang dilakukan oleh Nurul Sholeh yang berjudul "Strategi Penghimpunan Dan Penyaluran Dana Zakat Pada Lembaga Amil Zakat Al Ihsan Jawa Tengah (LAZIS JATENG) Cabang Kota Semarang (Studi Kepuasan Muzaki Dan Peningkatan, Pendapatan Mustahik)",strategi penyaluran dana zakat yang dilakukan adalah melalui kerjasama dan memalui program penyaluran dana zakat yang terdiri dari Economic Support, Education Support, Health Support, Dakwah Support serta berupa pemberian santunan. Dalam proses penyaluran dana zakat melalui beberapa proses yaitu: melakukan studi kelayakan, menetapkan program tepat guna, melakukan pendampingan, melakukan pengawasan, membuat laporan dan melakukan evaluasi.

Kepuasan muzaki pada LAZIS Jateng cabang Kota Semarang dikarenakan pelayanan yang diberikan oleh LAZIS Jateng cabang Kota Semarang, dari hasil penelitian mengenai kepuasan muzaki pada LAZIS Jateng cabang Kota Semarang, yang dilakukan terhadap 9 orang muzaki, mereka puas kepada LAZIS Jateng cabang Kota Semarang. Kualitas pelayanan yang paling banyak dirasakan muzaki adalah kategori daya tanggap (responsiveness).

\footnotetext{
${ }^{15}$ Khairuddin, Wakil Ketua II Baznas Provinsi Bali, Wawancara Terbuka, Denpasar 8 Juni 2020.

${ }^{16}$ Ibid.,

${ }^{17}$ Ibid.,

${ }^{18}$ Riang Bagus Dwi Anto, Staff Operasional Baznas Provinsi Bali, Loc. Cit.

${ }^{19}$ Ahmad Arrasyid, KPBP Zakat Baznas Provinsi Bali, Loc. Cit

${ }^{20}$ Riang Bagus Dwi Anto, Staff Operasional Baznas Provinsi Bali, Loc. Cit.

${ }^{21}$ Ibid.,
} 
Yang berbeda dengan penelitian ini adalah karena saat penelitian ini dilakukan sedang berada pada masa Covid-19 dimana penyalurannya memiliki perbedaan dengan tahun-tahun sebelumnya. Penyaluran yang dilakukan oleh Baznas Provinsi Bali (1) Sudah sesuai dengan syariah surat atTaubah ayat 60 dan sesuai dengan UU No 23 Tahun 2011, (2) Mengikuti protokol penanganan Covid19 dengan tetap physical distancing, social distancing, dan selalu pakai masker, (3) Pendekatan penyaluran dilakukan dengan MIX antara push approach dan pull approach, (4) Memberikan surat tembusan kepada gugus tugas Covid-19 yaitu ke BPD Bali dan MUI Bali crisis center.

\section{PENUTUP}

Berdasarkan hasil penelitian, analisis data, dan pembahasan mengenai "Strategi Penghimpunan dan Penyaluran ZIS Dalam Program Sebar Sembako Pada Masa Pandemi Covid-19 di Baznas Provinsi Bali'"maka dapat diambil kesimpulan sebagai berikut:

Pertama, bahwa strategi penghimpunan ZIS yang dilakukan Baznas Provinsi Bali yaitu (a) Sosialisasi dan Edukasi, (b) Mengirimkan laporan pertanggung jawaban keuangan, (c) Promosi Produk melalui tiga media yaitu media cetak, media sosial dan media elektronik, (d) Pembayaran ZIS bisa dilakukan dengan berbagai cara yaitu membayar di kantor Baznas Provinsi Bali, Pelayanan jemput zakat/infak/sedekah, Membentuk UPZ di masing-masing lembaga pemrintahan dan swasta, Pembayaran melalui transfer ke rekening bank yang sudah bekerjasama dengan Baznas Provinsi Bali, Pembayaran melalui scan barcode dengan aplikasi yang sudah bekerjasama dengan Baznas Provinsi Bali yaitu melalu Qris barcode di masing-masing Bank, Go Pay Merchant barcode, dan OVO barcode , (e) Menjalin hubungan yang baik dengan para muzaki/donatur.

Kedua, strategi Penyaluran ZIS untuk sembako di Baznas Provinsi adalah (a) Penyaluran ZIS untuk sembako sesuai dengan syariah surat at-Taubah ayat, 60 dan sesuai dengan UU No 23 Tahun 2011, (b) Mengikuti protokol penanganan Covid-19 dengan tetap physical distancing, social distanciingdan selalu pakai masker, (c) Pendekatan penyaluran dilakukan dengan MIX antara push approach dan pull approach, (d) Memberikan surat tembusan kepada gugus tugas Covid-19 yaitu ke BPD Bali dan MUI Bali crisis center.

Dengan ini peneliti bermaksud menyampaikan saran-saran yang diharapkan dapat berguna bagi Baznas Provinsi Bali, guna membangun strategi penghimpunan dan penyaluran lebih efektif dan efisien. Saran tersebut yaitu (1) Sosialisasi mengenai ZIS lebih ditingkatkan lagi, agar lebih mendomain ingatkan masyarakat mengenai ZIS dan pembayaran melalui Baznas Provinsi Bali; (2) Postingan di media sosial Baznas Provinsi Bali lebih aktif lagi dengan hastag/tagar tertentu agar lebih banyak dikenal oleh masyarakat dengan meningkatnya rating media sosial; (3) Membuat channel youtube agar masyarakat umum mengetahui kegiatan penghimpunan dan penyaluran ZIS oleh Baznas Provinsi Bali sehingga menarik minta Masyarakat untuk menunaikan zakatnya di Baznas Provinsi Bali; (4)Meningkatkan madrasah amil baik untuk baznas provinsi, kabupaten/kota dan amil Unit Pengumpulan Zakat (UPZ) guna mempermudah amil dalam sosialisasi

\section{DAFTAR RUJUKAN \\ BUKU}

Sujarweni, V. Wiratna. 2015. Metodologi Penelitian Bisnis dan Ekonomi. Yogyakarta: Pustakabarupress.

\section{SKRIPSI/JURNAL}

Hikmah. 2017. "Strategi Penghimpunan Dana Zakat Infak Sedekah (ZIS) Pada Griya Yatim \& Dhuafa Cabang Banjarmasin". (Online). (http://Scholar.google.com/idr.uin-antasari.ac.id/8442/, diakses 2 Mei 2020). Banjarmasin: UIN Antasari

Sholeh, Nurul. 2018. . 2018. "Strategi Penghimpunan Dan Penyaluran Dana Zakat Pada Lembaga Amil Zakat Al Ihsan Jawa Tengah (LAZIS JATENG) Cabang Kota Semarang (Studi Kepuasan Muzaki Dan Peningkatan, Pendapatan Mustahik)". (Online). (http://Scholar.google.com/repository.iainpurwokerto.ac.id, diakses 02 Mei 2020). Purwokerto:IAIN Purwokerto

\section{Al-Quran}

Departemen RI. Al-Quran. 2014. Terjemah dan Tajwid. Bandung: Sygma.

\section{Pernyataan Lisan}


Aminah. Siti. Mustahik Baznas Provinsi Bali. Wawancara Pribadi. Denpasar 8 April 2020

Anto, Riang Bagus Dwi.Staff Operasional Baznas Provinsi Bali. Wawancara Pribadi. Denpasar 8 Juni 2020

Indrawati. Muzaki Baznas Provinsi Bali. Wawancara Melalui Googel Form. Denpasar 6 Juni 2020

Khairuddin. Wakil Ketua II Baznas Provinsi Bali. Wawancara Pribadi. Denpasar 8 Juni 2020.

Mahrusun. Ketua Baznas Provinsi Bali. wawancara pribadi. Denpasar 4 Juni 2020

Rasyid. Manajer Operasional Baznas Provinsi Bali. Wawancara Pribadi. Denpasar 3 Juni 2020 